Arab Univ. J. Agric. Sci., Ain Shams Univ., Cairo, 13(2), 399 - 417, 2005

\title{
EFFECT OF IRRIGATION WITH SALINIZED WATER ON GROWTH AND CHEMICAL CONSTITUENTS OF "KALA- MATA" OLIVE CULTIVAR GRAFTED ONTO DIFFERENT OLIVE ROOTSTOCKS
}

[25]

\author{
Sanaa, I. Laz ${ }^{1}$
}

\begin{abstract}
The most important black table olive (Olea europaea L.) "Kalamata" cultivar, grafted onto three different vegetative olive rootstocks[Picual (Pic), Frantoio (Fra) and Koroneiki (Kor) cvs.] was evaluated with 2-year-old grafted plants grown in sand clay soil, and received concentrations of salt mixture $\left(\mathrm{NaCl}, \mathrm{Na}_{2} \mathrm{So}_{4}, \mathrm{CaCl}_{2}\right.$, $\mathrm{MgSo}_{4}$ and $\mathrm{KCl}$ ) making 6000 and $8000 \mathrm{ppm}$ with SAR 12 of salinity level, for two seasons. Morphological and chemical parameters were investigated to determine the relative salinity tolerance of these rootstocks and to define possible reasons for any observed differences in the salt tolerance. However, results indicated that differences in response to salinity among rootstocks were observed primarily in morphological traits. Increasing of salinity level in irrigation water decreased, all of scion height and its rate of increase, leaf area, number of leaves/plant and fresh \& dry weight of leaves and roots. But different rootstocks can affect the degree to which these parameters is reduced under salinity, where Kalamata growth on Picual and Frantoio was considerably better than on Koroneiki at 6000 and 8000 ppm treatments. Inversely in untreated grafted plants Kalamata on Kornaki exhibited the best growth vigor, comparing with $\mathrm{Kal} / \mathrm{Pic}$ or Kal/Fra plants, suggesting that a decrease of scion growth in untreated grafted plants is a salt tolerance quality transmitted by tolerant rootstocks. Salinity significantly decreased leaf chlorophyll (a) and (b) content of all grafted plants, but different content among rootstocks were noted. On the contrary, proline content increased in leaves of all treated plants, however, insignificant difference was noted between rootstocks, yet the interaction between the two factors show that Kalamata on Picual and on Frantoio rootstocks recorded higher values of leaf proline content than Kalamata on Koroneiki rootstock. Leaves and roots $\mathrm{Na}^{+}$ and $\mathrm{Cl}^{-}$content of treated grafted plants showed an increment but to a different degree, comparing with the untreated (control) plants. There were differences among the grafted plants where Kalamata grafted on Koroneiki (the least tolerant cv.) mostly affected by saline treatment and accumulated the highest content of $\mathrm{Na}^{+}$and $\mathrm{Cl}^{-}$in leaves comparing with Kalamata on Picual (the most tolerant cv.) or on Frantoio (the
\end{abstract}

1- Olive \& Semiarid Zone Fruits Res. Dept., Hort. Res. Institute, Agric. Res. Centre. Giza, Egypt 
moderate tolerant cv.). Tolerant rootstocks contained more $\mathrm{Na}^{+}$in roots than in leaves. This response become apparent as salinity increased. Leaf $\mathrm{N}, \mathrm{P}$ and $\mathrm{K}$ contents decreased in Kalamata leaves as influenced by different rootstocks and increasing salinity in irrigation water comparing with the control. Kal/Pic and Kal/Fra plants had higher $\mathrm{N} \%$ in leaves than $\mathrm{Kal} / \mathrm{Kor}$ plants, whereas $\mathrm{Kal} / \mathrm{Pic}$ accumulated $\mathrm{K}$ more than the other plants, while $\mathrm{P}$ content in leaves of all grafted plants were insignificant in the two seasons. Based on the overall growth parameters and chemical composition in response to salinity, Kalamata grafted on Picual exhibited the greatest salt tolerance followed by those grafted on Frantoio whereas, Kalamata on Koroneiki showed the poorest plants pertaining salt tolerance.

Key words: Grafting, Irrigation with salinized water, Olive cultuivars, Rootstocks, Salt stress

\section{INTRODUCTION}

Olive (Olea europaea L.) is a major crop in the countries of the Mediterranean Sea basin and in many semiarid areas of the world, in these areas large quantities of low quality water, mostly saline are available and could be used for olive irrigation (Loupassaki et al 2002). Although it classified as a moderately salt tolerant (Tattini et al 1992), olive is well known as a crop capable to grow successfully and giving substantial yields when irrigated with saline water unsuitable for other fruit tree crops (Taha et al 1972; Tattini, et al 1994; El-Sayed et al 1996 and Tattini et al 1997).

Salinity tolerance in olive is a cultivar depended characteristic (Tattini et al 1997). However, symptoms of toxicity and cultivar differences in susceptibility to high concentrations of salts have been described by Bartolini et al (1991) and Laupassaki et al (2002). They reported that, marked saline stress can produce accumulation of sodium $\left(\mathrm{Na}^{+}\right)$and chloride $\left(\mathrm{Cl}^{-}\right)$in olive leaves, decreased growth, alter photosynthesis, cause morphological changes in the leaves and de- crease the concentration of nutrients affecting, the nutrition of the tree.

Recent data on physiological mechanisms involved in olive salt tolerance might help to interpret data concerning scion-rootstock combinations, Therios and Misopolions (1988); Al-Absi et al (2003) suggested that, the exclusion of $\mathrm{Na}^{+}$and $\mathrm{Cl}^{-}$from leaves is the main mechanism of salt tolerance in olive, Tattini et al (1994) and Loupassaki et al (2002), concluded that, the mechanisms of salt tolerance in olives should be located within the roots preventing net salt export to the shoot, rather than salt absorption.

Plant adaptation to saline conditions can depend, also on an increase in specific organic solutes within the cell, which help in osmoregulation and in preventing salt accumulation within the cytoplasm (Stewart and Lee 1974; Flower et al 1977).

Rootstock can import stress tolerance to the scion and that the beneficial effect of the rootstock is often the exclusion of $\mathrm{Na}^{+}$and /or $\mathrm{Cl}^{-}$from the scion, (Michael and Mary, 2002). This has been demonstrated clearly in citrus (Banuls et al 
1990), while there appears to be a correlation between leaf $\mathrm{Na}^{+}$or $\mathrm{Cl}^{-}$concentrations and physiological responses to salinity in some citrus rootstock-Scion combinations (Lloyd et al 1987).

The objective of the present study was to:

1. Evaluate the performance of the most important black table olive "Kalamata" cultivar, when grafted on three different vegetative olive rootstocks and irrigated with different saline water solution.

2. Determine the uptake and accumulation of $\mathrm{Na}^{+}$and $\mathrm{Cl}^{-}$ions in the leaves of grafted plants under salt stress.

3. Define the effect of salt stress on the leaf mineral status of grafted plants.

\section{MATERIAL AND METHODS}

The experiment was conducted in the greenhouse of the experimental orchard of the Horticulture Research Institute, Giza, Governorate, Egypt. during 2001, 2002 and 2003 seasons. Trial was done to evaluate the effect of irrigation with salinized water on growth and chemical constituents of Kalamata "kal" olive cultivars grafted onto three different vegetative olive rootstocks i.e. Picual "Pic" "the most tolerant cv.", Frantoio "Fra" "moderate tolerant cv." and Koroneiki "Kor" "as sensitive one", according to Tattini $\boldsymbol{e t}$ al (1994); El-Sayed et al (1996); Tattini et al

(1997)

and Loupassaki et al (2002).

Scions of Kalamata olive cv. were grafted on each of the three different oneyear-old vegetative rootstocks in February 2001 and 2002 seasons. Grafted plants were maintained under the experimental field conditions for one year in polyethylene containers. Beginning with Mach 2002 and 2003 seasons, the two- years- old chosen grafted plants were uniform in vigor and trimmed to a single main trunk, transplanted into plastic pots of $25 \mathrm{~cm}$ in diameter and $30 \mathrm{~cm}$ in depth, containing $6 \mathrm{Kgs} /$ pot of sandy clay loam soil, free from salts taken in February from a depth of $30 \mathrm{~cm}$ from the surface soil layer of Ismaillia Governorate, Egypt. Some physical and chemical properties of the used soil in this study were done by Soil, Water and environment. Res. Inst .Agric .Res.center, according to the method as descried by Jackson, (1973) and were summarized in Table (1).

The grafted plants were irrigated twice weekly by tap water before application saline solutions up to early May for each season.

The experiment included 9 blocks $\{3$ treatments $\mathrm{x}$ grafted plants on 3 different rootstocks (Kal/ Pic, Kal/ Fra and $\mathrm{Kal} / \mathrm{Kor})$ \}, comprising 3 replicates, each one consisted of 9 plants, to receive one of salt treatment and arranged in a factorial complete randomized design. The grafted plants were irrigated with salinized water with dissolving amount of $\mathrm{NaCl}, \mathrm{Na} \mathrm{So}_{4}, \mathrm{CaCl}_{2}, \mathrm{MgSo}_{4}$ and $\mathrm{KCl}$ salts making concentration of 6000 and 8000 ppm with SAR (Sodium adsorption ratio) 12 calculated on the basis of the following equation.

$$
S A R=\frac{N A}{\sqrt{C a+M g / 2}}
$$

The untreated (control) plants were irrigated with tap water (400 ppm). Irrigation with saline solutions carried out twice weekly using $750 \mathrm{ml} . /$ pot, started in the first week of May and ended at late November in the two successive seasons (2002 and 2003). 
Table 1. Physical and Chemical properties of the experimented soil

\section{(A) Physical properties}

\begin{tabular}{|cccccccc|}
\hline \multirow{2}{*}{$\begin{array}{c}\text { Saturation } \\
\text { Percent }\end{array}$} & \multicolumn{2}{c}{ Partial size distribution } & & Textural class & F.C.* & W.P.** \\
\cline { 2 - 4 } & Total sand & Silt & Clay & & & \\
\hline $20 \%$ & 69.7 & 25.3 & 5 & Sand loam & $16 \%$ & $3 \%$ \\
\hline
\end{tabular}

(B) Chemical properties

\begin{tabular}{|cccccccccccc|}
\hline & & \multicolumn{4}{c}{ Soluble cations (me/l) } & \multicolumn{4}{c|}{ Soluble anions (me/l) } & $\mathrm{Caco}_{3}$ \\
\cline { 3 - 9 } E.C & $\mathrm{PH} * *$ & $\mathrm{Na}^{+}$ & $\mathrm{K}^{+}$ & $\mathrm{Ca}^{+}$ & $\mathrm{Mg}^{++}$ & $\mathrm{Hco}_{3}^{-}$ & $\mathrm{Co}_{3}^{-}$ & $\mathrm{Cl}^{-}$ & $\mathrm{So}_{4}^{-}$ & \\
\hline 1.35 & 8.26 & 26.75 & 2.20 & 43.90 & 12.60 & 9.00 & - & 43.60 & 32.85 & 2.17 \\
\hline
\end{tabular}

F. $C^{*}=$ Field capacity. W.P**= Wilting Point. E.C ${ }^{* * *}=$ Electrical Conductivity $\left(\mathrm{m} \cdot \mathrm{mhos} / \mathrm{cm}^{3}\right)$.

Leaching of accumulated salts was done every 21 days by irrigation with tap water to reach approximately $\mathrm{EC}(0.29-$ $0.31 \mathrm{~m} . \mathrm{moles})$, followed by re-watering with the corresponding saline solutions in the next day. Control treatment was irrigated by tap water at the same rate. Hoagland solution (Hoagland and Arnon, 1950) was added biweekly for all treatments through the growth period.

At the end of the growth in each season, nine plants (representing 3 replicates) were sampled for each treatment and carefully pulled from the pots, washed and air dried and were used for the following determinations:

\section{I- Vegetative growth parameters}

1. Average scion height $(\mathrm{cm})$ and its rate of increase ( $\mathrm{cm} /$ season).
2. Number of leaves / plant.

3. Leaf area $\left(\mathrm{cm}^{2}\right)$ was estimated from the equation of

(Leon \& Bukovac, 1978 and Tattini et al 1997):

Leaf area $=0.717 \mathrm{X}-0.095)$ where $\mathrm{X}$ is the product of length by width.

4. Fresh and dry weight of leaves and roots in grams.

\section{II- Chemical constituents}

\section{Foliar pigments}

Representative leaf samples of the same physiological age and position were taken in both seasons. Photosynthetic pigments (chlorophyll a, and b) in response to salinity were quantitatively determined in samples of sufficient fresh leaves. The optical densities were meas- 
ured colorimetrically at 660 and $640 \mu \mathrm{M}$. wave for chlorophyll a, and b content, respectively according to Saric et al (1967).

\section{Leaf proline content}

Proline content g/100g F.W. was colorimetrically estimated in fresh leaf samples according to the methods of Bates $\boldsymbol{e t}$ al (1973).

\section{Minerals content}

Leaves and root samples were dried at $70 \circ \mathrm{c}$ till a constant weight, then ground and used for subsequent determination of $\mathrm{N}, \mathrm{P}, \mathrm{K}, \mathrm{Na}$ and $\mathrm{Cl}$ in each sample as follows:

a) Nitrogen was determined by the modified micro-Kjeldahl method as described by Pregl, (1945).

b) Phosphorus was determined colorimetrically according to A.O.A.C. (1970).

c) Potassium and Sodium were determined by atomic emission analysis A.O.A.C. (2000).

d) Chloride was extracted from ash samples with hot water and titrated with standard silver nitrate solution and then determined according to A.O.A.C. (1970).

\section{Statistical analysis}

All data of 2002 and 2003 experimental seasons were subjected to analysis of variance according to Snedecor and Cochran (1980) and means were differentiated using Duncan's multiple tests (Duncan, 1955).

\section{RESULTS}

\section{I- Vegetative growth parameters}

The vegetative growth parameters were tested and evaluated under the same experimental conditions in both 2002 and 2003 seasons.

\section{Average scion height and its rate of increase}

Data presented in Table (2) show that, increasing of salinity levels in irrigation water affected negatively in the scion height of grafted olive plants, regardless of the kind of rootstocks. The data concerning the rate of increase clearly indicate that kalamata scion on all rootstocks was reduced during growth flush by increasing the salinity level, resulting in a significant reduction in rate of scion height, such reduction was more drastic by raising the salinity level, where it was $14.72,8.84 \& 6.10 \mathrm{~cm} /$ in the first season and $14.08,8.20 \& 5.71 \mathrm{~cm} /$ in the second season, for the grafted plants which irrigated with saline solution 400 (control), 6000 and 8000 ppm, respectively. These results are generally in line with those previously reported by El-Sayed $\boldsymbol{e t}$ al (1996); Tattini et al (1997) and Atia (2002) on olive cultivars, as well as, Bondok et al (1995) on peach and Michael and Mary (2002) on avocado.

Regarding the kind of rootstocks and its effect on scion growth in grafted plants, data show that, there was conspicuous increase in Kalamata scion grafted on Picual rootstock where it recorded higher values of increasing rate $(11.63 \&$ 11.49) than that on the other two rootstocks, which recorded (10.06 \& 9.32) and $(7.98 \& 7.18)$ in the two successive seasons, respectively. 
Table 2. Average scion height $(\mathrm{cm})$ and rate of increase $(\mathrm{cm} / \mathrm{season})$ of Kalamata olive cv. grafted on different rootstocks as influenced by salinity treatments in irrigation water, during 2002 and 2003 seasons

\begin{tabular}{|c|c|c|c|c|c|c|c|c|}
\hline \multirow[b]{3}{*}{ Treatments } & \multicolumn{4}{|c|}{ Average scion height $(\mathrm{cm})$} & \multicolumn{4}{|c|}{ Rate of height increase (cm/season) } \\
\hline & \multicolumn{8}{|c|}{2002} \\
\hline & control & $\begin{array}{l}6000 \\
\mathrm{ppm}\end{array}$ & $\begin{array}{l}8000 \\
\text { ppm }\end{array}$ & Mean & control & $\begin{array}{l}6000 \\
\mathrm{ppm}\end{array}$ & $\begin{array}{l}8000 \\
\text { ppm }\end{array}$ & Mean \\
\hline $\mathrm{Kal} / \mathrm{Pic}$ & $38.20 \mathrm{~b}$ & $36.03 \mathrm{c}$ & $33.00 \mathrm{~d}$ & $35.74 \mathrm{~A}$ & $14.20 \mathrm{~b}$ & $11.70 \mathrm{c}$ & $9.00 \mathrm{e}$ & $11.63 \mathrm{~A}$ \\
\hline $\mathrm{Kal} / \mathrm{Fra}$ & $38.43 \mathrm{~b}$ & $33.33 \mathrm{~d}$ & $30.20 \mathrm{e}$ & $33.98 \mathrm{~B}$ & $14.50 \mathrm{~b}$ & $9.40 \mathrm{~d}$ & $6.27 \mathrm{f}$ & $10.06 \mathrm{~B}$ \\
\hline $\mathrm{Kal} / \mathrm{Kor}$ & $40.20 \mathrm{a}$ & $30.17 \mathrm{e}$ & $27.77 \mathrm{f}$ & $32.71 \mathrm{~B}$ & $15.47 \mathrm{a}$ & $5.43 \mathrm{~g}$ & $3.03 \mathrm{~h}$ & $7.98 \mathrm{C}$ \\
\hline Mean & $38.94 \mathrm{~A}$ & $33.18 \mathrm{~b}$ & $30.32 \mathrm{C}$ & & $14.72 \mathrm{~A}$ & $8.84 \mathrm{~B}$ & $6.10 \mathrm{C}$ & \\
\hline Parameters & \multicolumn{4}{|c|}{ Average scion height $(\mathrm{cm})$} & \multicolumn{4}{|c|}{ Rate of height increase ( $\mathrm{cm} / \mathrm{season})$} \\
\hline \multirow[b]{2}{*}{ Treatments } & \multicolumn{8}{|c|}{2003} \\
\hline & control & $\begin{array}{l}6000 \\
\mathrm{ppm}\end{array}$ & $\begin{array}{l}8000 \\
\text { ppm }\end{array}$ & Mean & control & $\begin{array}{l}6000 \\
\mathrm{ppm}\end{array}$ & $\begin{array}{l}8000 \\
\text { ppm }\end{array}$ & Mean \\
\hline $\mathrm{Kal} / \mathrm{Pic}$ & $36.27 \mathrm{~b}$ & $33.53 \mathrm{c}$ & $31.17 \mathrm{~d}$ & $33.79 \mathrm{~A}$ & $13.97 \mathrm{a}$ & $11.63 \mathrm{~b}$ & $8.87 \mathrm{c}$ & $11.49 \mathrm{~A}$ \\
\hline $\mathrm{Kal} / \mathrm{Fra}$ & $36.33 \mathrm{~b}$ & $30.77 \mathrm{e}$ & $27.67 \mathrm{~g}$ & $31.59 \mathrm{~B}$ & $14.07 \mathrm{a}$ & $8.50 \mathrm{~d}$ & $5.40 \mathrm{e}$ & $9.32 \mathrm{~B}$ \\
\hline $\mathrm{Kal} / \mathrm{Kor}$ & $38.00 \mathrm{a}$ & $28.27 \mathrm{f}$ & $26.67 \mathrm{~h}$ & $30.98 \mathrm{~B}$ & $14.20 \mathrm{a}$ & $4.47 \mathrm{f}$ & $2.87 \mathrm{~g}$ & $7.18 \mathrm{C}$ \\
\hline Mean & $36.87 \mathrm{~A}$ & $30.99 \mathrm{~B}$ & $28.50 \mathrm{C}$ & & $14.08 \mathrm{~A}$ & $8.20 \mathrm{~B}$ & $5.71 \mathrm{C}$ & \\
\hline Parameters & \multicolumn{4}{|c|}{ No. of leaves/plant } & \multicolumn{4}{|c|}{ Leaf area $(\mathrm{cm} 2)$} \\
\hline \multirow[b]{2}{*}{ Treatments } & \multicolumn{8}{|c|}{2002} \\
\hline & control & $\begin{array}{l}6000 \\
\mathrm{ppm}\end{array}$ & $\begin{array}{l}8000 \\
\text { ppm }\end{array}$ & Mean & control & $\begin{array}{l}6000 \\
\mathrm{ppm}\end{array}$ & $\begin{array}{l}8000 \\
\text { ppm }\end{array}$ & Mean \\
\hline $\mathrm{Kal} / \mathrm{Pic}$ & $184.3 \mathrm{~b}$ & $159.0 \mathrm{c}$ & $115.3 \mathrm{f}$ & $152.9 \mathrm{~A}$ & $3.45 \mathrm{a}$ & $3.26 \mathrm{~b}$ & $3.08 \mathrm{~d}$ & $3.27 \mathrm{~A}$ \\
\hline $\mathrm{Kal} / \mathrm{Fra}$ & $185.3 \mathrm{~b}$ & $154.0 \mathrm{~d}$ & $92.67 \mathrm{~g}$ & $144.0 \mathrm{~B}$ & $3.44 \mathrm{a}$ & $3.17 \mathrm{c}$ & $3.03 \mathrm{~d}$ & $3.21 \mathrm{~A}$ \\
\hline $\mathrm{Kal} / \mathrm{Kor}$ & 195.3 a & $126.3 \mathrm{e}$ & $57.00 \mathrm{~h}$ & $126.2 \mathrm{C}$ & $3.43 \mathrm{a}$ & $3.07 \mathrm{~d}$ & $2.82 \mathrm{e}$ & $3.11 \mathrm{~B}$ \\
\hline Mean & $188.3 \mathrm{~A}$ & $146.4 \mathrm{~B}$ & $88.33 \mathrm{C}$ & & $3.44 \mathrm{~A}$ & $3.17 \mathrm{~B}$ & $2.98 \mathrm{C}$ & \\
\hline Parameters & \multicolumn{4}{|c|}{ No. of leaves/plant } & \multicolumn{4}{|c|}{ Leaf area $(\mathrm{cm} 2)$} \\
\hline \multirow[b]{2}{*}{ Treatments } & \multicolumn{8}{|c|}{2003} \\
\hline & control & $\begin{array}{l}6000 \\
\mathrm{ppm}\end{array}$ & $\begin{array}{l}8000 \\
\mathrm{ppm}\end{array}$ & Mean & control & $\begin{array}{l}6000 \\
\mathrm{ppm}\end{array}$ & $\begin{array}{l}8000 \\
\mathrm{ppm}\end{array}$ & Mean \\
\hline $\mathrm{Kal} / \mathrm{Pic}$ & $177.7 \mathrm{~b}$ & $157.0 \mathrm{c}$ & $102.0 \mathrm{f}$ & $145.6 \mathrm{~A}$ & $3.46 \mathrm{a}$ & $3.11 \mathrm{~b}$ & $2.93 \mathrm{c}$ & $3.16 \mathrm{~A}$ \\
\hline $\mathrm{Kal} / \mathrm{Fra}$ & $183.0 \mathrm{a}$ & $145.7 \mathrm{~d}$ & $91.33 \mathrm{~g}$ & $140.0 \mathrm{~B}$ & $3.38 \mathrm{a}$ & $3.07 \mathrm{~b}$ & $2.65 \mathrm{~d}$ & $3.03 \mathrm{~B}$ \\
\hline $\mathrm{Kal} / \mathrm{Kor}$ & $181.3 \mathrm{a}$ & $110.0 \mathrm{e}$ & $43.00 \mathrm{~h}$ & $111.4 \mathrm{C}$ & $3.41 \mathrm{a}$ & $2.98 \mathrm{c}$ & $2.60 \mathrm{~d}$ & $3.00 \mathrm{~B}$ \\
\hline Mean & $180.7 \mathrm{~A}$ & $137.6 \mathrm{~B}$ & $78.78 \mathrm{C}$ & & $3.42 \mathrm{~A}$ & $3.05 \mathrm{~B}$ & $2.72 \mathrm{C}$ & \\
\hline
\end{tabular}


Concerning, the interaction between salinity levels and different olive rootstocks on the average scion height and its rate of increase data clearly show that both of the two factors affect significantly on such parameters.

From the obtained results, it could be also noticed that, although in the grafted plants Kal/Pic exhibited the highest values of average scion height and its rate of increase, comparing with Kal/Kor which appeared the lowest ones, contrariwise in untreated grafted plants Picual rootstock induced shorter scion height, in comparison with Koroneiki rootstock which exhibited the highest values of scion height in both seasons. These results suggesting that a reduction of scion growth in the untreated grafted plants is a sold tolerance quality transmitted by tolerant rootstocks, these data are agree with those of Jose et al (2002) and Syvertsen et al (1989), who indicated that there are significant negative relationships between vigour and salt tolerance.

Generally, it could be concluded that, different rootstocks can affect the degree to which olive scion growth is reduced under salinity.

\section{Number of leaves/plant}

The salinization response of grafted olive plants, presented in Table (2), indicate that, the maximum total leaves number per Kalamata scion were obtained when the grafted plants were irrigated with saline water $400 \mathrm{ppm}$ (control) $188.31 \& 180.70$ in contrast to the plants irrigated with $8000 \mathrm{ppm}$ (the highest salt stress) $88.33 \& 78.78$ in the two seasons, respectively.

Recorded data concerning the effect of different rootstocks, showed that, kal/ Pic plants had higher number of leaves than Kal/ Fra or Kal/ Kor plants when irrigated with saline water.

Results indicate that number of leaves in the grafted plants was in consequence of both salinity levels and kind of rootstock in grafted plants with the same scion. The same results were found by Kaul, (1981) on guava and Bondok et al (1995) on peach.

\section{Leaf area $\left(\mathrm{cm}^{2}\right)$}

Results reported in Table (2) clearly show that, in both seasons, the leaf area was significantly decreased by increasing salinity levels in irrigation water. The reduction in leaf growth is probably due to increase in osmotic pressure of the growth medium, depress water absorption or excess of certain ions which seem to have specific toxic impact especially sodium (Bernstein, 1965).

The results, indicated that, the leaf growth was affected differently to salinity stress depending on the rootstocks, whereas Kalamata scion grafted on Picual rootstock gave the highest values of leaf area, while the reduction in leaf area in response to salinity was observed in Kalamata on Koroneiki which gave plants with narrow leaf area, thus low in building metabolism and low in tolerance to salinity stress. These results are in harmony with those mentioned by Kaul (1981) on guava, Bondok et al (1995) on peach and Michael and Mary (2002) on avocado.

\section{Fresh and dry weight of leaves and roots}

Data presented in Tables (3) indicates that, different salt concentrations in an irrigation water resulted in a significant 
Table 3. Average fresh and dry weight of leaves and roots (gm) Kalamata olive cv. grafted on different rootstocks as influenced by salinity treatments in irrigation water, during 2002 and 2003 seasons

\begin{tabular}{|c|c|c|c|c|c|c|c|c|}
\hline \multirow[b]{3}{*}{ Treatments } & \multicolumn{4}{|c|}{ Fresh weight of leaves (gm) } & \multicolumn{4}{|c|}{ Dry weight of leaves (gm) } \\
\hline & \multicolumn{8}{|c|}{2002} \\
\hline & Control & $\begin{array}{l}6000 \\
\mathrm{ppm}\end{array}$ & $\begin{array}{l}8000 \\
\mathrm{ppm}\end{array}$ & Mean & Control & $\begin{array}{l}6000 \\
\mathrm{ppm}\end{array}$ & $\begin{array}{l}8000 \\
\text { ppm }\end{array}$ & Mean \\
\hline $\mathrm{Kal} / \mathrm{Pic}$ & $25.87 \mathrm{a}$ & $22.11 \mathrm{c}$ & $17.31 \mathrm{e}$ & $21.76 \mathrm{~A}$ & $12.79 \mathrm{~b}$ & $9.96 \mathrm{c}$ & $8.36 \mathrm{e}$ & $10.37 \mathrm{~A}$ \\
\hline $\mathrm{Kal} / \mathrm{Fra}$ & $25.33 \mathrm{~b}$ & $20.48 \mathrm{~d}$ & $12.60 \mathrm{~g}$ & $19.47 \mathrm{~B}$ & $12.39 \mathrm{~b}$ & $8.84 \mathrm{~d}$ & $5.78 \mathrm{~g}$ & $9.19 \mathrm{~B}$ \\
\hline $\mathrm{Kal} / \mathrm{Kor}$ & $25.97 \mathrm{a}$ & $16.11 \mathrm{f}$ & $7.11 \mathrm{~h}$ & $16.39 \mathrm{C}$ & $13.33 \mathrm{a}$ & $7.00 \mathrm{f}$ & $2.55 \mathrm{~h}$ & $7.63 \mathrm{C}$ \\
\hline Mean & $25.72 \mathrm{~A}$ & $19.57 \mathrm{~B}$ & $12.34 \mathrm{C}$ & & $13.02 \mathrm{~A}$ & $8.60 \mathrm{~B}$ & $5.56 \mathrm{C}$ & \\
\hline Parameters & \multicolumn{4}{|c|}{ Fresh weight of leaves (gm) } & \multicolumn{4}{|c|}{ Dry weight of leaves (gm) } \\
\hline \multirow[b]{2}{*}{ Treatments } & \multicolumn{8}{|c|}{2003} \\
\hline & Control & $\begin{array}{l}6000 \\
\mathrm{ppm}\end{array}$ & $\begin{array}{l}8000 \\
\text { ppm }\end{array}$ & Mean & Control & $\begin{array}{l}6000 \\
\mathrm{ppm}\end{array}$ & $\begin{array}{l}8000 \\
\mathrm{ppm}\end{array}$ & Mean \\
\hline $\mathrm{Kal} / \mathrm{Pic}$ & $25.77 \mathrm{a}$ & $21.45 \mathrm{c}$ & $17.50 \mathrm{e}$ & $21.38 \mathrm{~A}$ & $12.38 \mathrm{a}$ & $8.28 \mathrm{~b}$ & $6.98 \mathrm{c}$ & $9.21 \mathrm{~A}$ \\
\hline $\mathrm{Kal} / \mathrm{Fra}$ & $25.03 \mathrm{~b}$ & $18.40 \mathrm{~d}$ & $12.29 \mathrm{~g}$ & $18.58 \mathrm{~B}$ & $12.49 \mathrm{a}$ & $8.17 \mathrm{~b}$ & $5.14 \mathrm{e}$ & $8.60 \mathrm{~A}$ \\
\hline $\mathrm{Kal} / \mathrm{Kor}$ & $24.74 \mathrm{~b}$ & $14.10 \mathrm{f}$ & $5.75 \mathrm{~h}$ & $14.86 \mathrm{C}$ & $12.68 \mathrm{a}$ & $5.92 \mathrm{~d}$ & $2.48 \mathrm{f}$ & $7.03 \mathrm{~B}$ \\
\hline Mean & $25.18 \mathrm{~A}$ & $17.98 \mathrm{~B}$ & $11.84 \mathrm{C}$ & & $12.51 \mathrm{~A}$ & $7.45 \mathrm{~B}$ & $4.87 \mathrm{C}$ & \\
\hline Parameters & \multicolumn{4}{|c|}{ Fresh weight of roots (gm) } & \multicolumn{4}{|c|}{ Dry weight of roots (gm) } \\
\hline \multirow{3}{*}{ Treatments } & \multicolumn{8}{|c|}{2002} \\
\hline & Control & 6000 & 8000 & Mean & Control & 6000 & 8000 & Mean \\
\hline & & ppm & ppm & & & $\mathrm{ppm}$ & ppm & \\
\hline $\mathrm{Kal} / \mathrm{Pic}$ & $53.92 \mathrm{~b}$ & $48.25 \mathrm{c}$ & $39.86 \mathrm{~d}$ & $47.34 \mathrm{~A}$ & $23.67 \mathrm{~b}$ & $20.53 \mathrm{~d}$ & $16.48 \mathrm{f}$ & $20.22 \mathrm{~A}$ \\
\hline $\mathrm{Kal} / \mathrm{Fra}$ & $53.65 \mathrm{~b}$ & $39.08 \mathrm{e}$ & $31.36 \mathrm{~g}$ & $41.36 \mathrm{~B}$ & $23.24 \mathrm{c}$ & $17.48 \mathrm{e}$ & $13.93 \mathrm{~g}$ & $18.22 \mathrm{~B}$ \\
\hline $\mathrm{Kal} / \mathrm{Kor}$ & $55.03 \mathrm{a}$ & $35.36 \mathrm{f}$ & $26.50 \mathrm{~h}$ & $38.96 \mathrm{C}$ & $24.14 \mathrm{a}$ & $14.13 \mathrm{~g}$ & $11.33 \mathrm{~h}$ & $16.53 \mathrm{C}$ \\
\hline Mean & $54.20 \mathrm{~A}$ & $40.90 \mathrm{~B}$ & $32.57 \mathrm{C}$ & & $23.68 \mathrm{~A}$ & $17.38 \mathrm{~B}$ & $13.91 \mathrm{C}$ & \\
\hline Parar & & sh & 0015 & & & ig & 11 & \\
\hline \multirow{3}{*}{ Treatments } & \multicolumn{8}{|c|}{2003} \\
\hline & Control & 6000 & 8000 & Mean & Control & 6000 & 8000 & Mean \\
\hline & & $\mathrm{ppm}$ & $\mathrm{ppm}$ & & & $\mathrm{ppm}$ & $\mathrm{ppm}$ & \\
\hline $\mathrm{Kal} / \mathrm{Pic}$ & $48.92 \mathrm{~b}$ & $46.13 \mathrm{c}$ & $37.05 \mathrm{~d}$ & $44.03 \mathrm{~A}$ & $21.00 \mathrm{~b}$ & $18.98 \mathrm{c}$ & $15.46 \mathrm{~d}$ & $18.48 \mathrm{~A}$ \\
\hline $\mathrm{Kal} / \mathrm{Fra}$ & $48.65 \mathrm{~b}$ & $36.96 \mathrm{~b}$ & $29.81 \mathrm{f}$ & $38.47 \mathrm{~B}$ & $21.77 \mathrm{a}$ & $15.71 \mathrm{~d}$ & $12.09 \mathrm{f}$ & $16.52 \mathrm{~B}$ \\
\hline $\mathrm{Kal} / \mathrm{Kor}$ & $49.86 \mathrm{a}$ & $33.59 \mathrm{e}$ & $24.94 \mathrm{~g}$ & $36.13 \mathrm{C}$ & $22.12 \mathrm{a}$ & $13.84 \mathrm{e}$ & $10.09 \mathrm{~g}$ & $15.35 \mathrm{C}$ \\
\hline Mean & $49.14 \mathrm{~A}$ & $38.89 \mathrm{~B}$ & $30.60 \mathrm{C}$ & & $21.63 \mathrm{~A}$ & $16.18 \mathrm{~B}$ & $12.55 \mathrm{c}$ & \\
\hline
\end{tabular}


reduction with different degrees in fresh and dry weight of leaves and roots of olive grafted plants, when compared with those of control plants in 2002 and 2003 seasons. These results are coinciding with those of Bartolini et al (1991); El-Sayed et al (1996); Micheal and Mary (2002). Such reduction in plant growth might be due to low available water for tissue development rather than deficiency of inorganic nutrient supply (Cooper et al 1952).

Data in both seasons showed that, although the untreated grafted plants $\mathrm{Kal} / \mathrm{Kor}$ exhibited the highest values of fresh and dry weight of roots comparing with $\mathrm{Kal} / \mathrm{Pic}$ or $\mathrm{Kal} / \mathrm{Fra}$, they appear the lowest value in the grafted plants irrigated with saline water. The obtained results may confirm that previously discussed by Tattini et al (1994) that, root vigour was positively related to cultivar vigour and negatively related to salt tolerance.

Hartmann and Kester (1968), found that, there are three approaches that could be put into considerations to explain the scion-rootstock relationship affecting plant growth, these approaches are, nutritional uptake utilization, translocation of nutrient water and alterations in endogenous growth factor. These three factors generally affected growth of the scion expressed as dry weight.

In general, results clearly show that, salt tolerance response based on these growth parameters (average scion height and its rate of increase; number of leaves/plant, leaf area and fresh and dry weight of leaves and roots) for each rootstock-scion combination resulting in a reduction in scion growth.

Results also, indicated that, salt tolerance of grafted plants generally depended on the characteristics of the rootstocks in response to salinized irrigation water.

\section{Chemical constituents}

\section{(1) Foliar pigments}

The data obtained in the present study pertaining the chlorophyll (a) and (b) contents are shown in Table (4). These results reveal that, salinity significantly decreased the leaf foliar pigments content of all grafted plants. It has been noticed that the reduction in chlorophyll (a) and (b) content was correlated with the increase in salinity concentrations. Results also show that, different rootstocks exhibited significant variation in chlorophyll (a) \& (b) in the two seasons.

Regarding to the interaction between salinity level and different olive rootstocks on foliar pigments content, results show that, significant variations were noted between grafted plants, where Kal/ Pic exhibited the highest values of chlorophyll (a) and (b), while, Kal/ Far recorded a moderate content, and Kal / Kor gave the lowest values.

The reduction in chlorophyll content as affected by saline irrigation water was previously reported by El-Sayed $\boldsymbol{e t}$ al (1996) and Atia (2002) on olive. The results also similar to those reported by Ferguson et al (2002) on "Kerman" Pistachio on three rootstocks.

Reductions in chlorophyll content of plants treated with salinized water have been also studied by Jacobson and Ortli (1956) who suggested that the depressive effect of salinity on the absorption of ions such as iron was involved in chloroplast formation via protein synthesis. In addition, Puritch and Barker (1967) proved that ammonium accumulation in plant 
leaves was one of the main factors causing reduction in chlorophyll content through plastid breakdown.

\section{(2) Proline content}

Proline content indicates remarkable increase in the leaves of all treated grafted plants irrigated with saline water, (Table, 4).

Data concerning the effect of different rootstocks showed that, Kalamata olive cv. grafted on Picual, Frantoio or Koroneiki olive rootstocks contained nearly similar amount of proline in all cases and the difference were insignificant in the two studied seasons.

Regarding the interaction between salinity level and different olive rootstocks on proline content, it is clear that, both of the two factors affect significantly the proline content and significant variation were noted between the grafted plants. However, leaves of Kalamata cv. grafted on Picual rootstock has recorded the highest values of proline content compared to those grafted on Frantoio or Koroneiki rootstocks. These may confirm those reported by Bates et al (1973); Stewart and Lee (1974) who mentioned that proline was increased gradually as the level of salinity raised, they also suggested that, proline function as a source of solute for intra cellular osmotic adjustments under saline conditions.

\section{(3) Ion concentration}

\section{(a) Sodium and chloride contents}

In comparison with the control grafted plants, salinized water treatments increased significantly $\mathrm{Na}^{+}$and $\mathrm{Cl}^{-}$concentration in leaves and roots (Tables $5 \& 6$ ).
There were differences among the grafted plants where Kal/Kor plants mostly affected by salinity treatment and accumulated the highest values of $\mathrm{Na}^{+}$in leaves(2.604 \& 2.738) comparing with Kal/ Far (2.066 \& 2.121) or Kal/Pic (1.621 \& 1.653),when exposed the highest salinity level $(8000 \mathrm{ppm})$ in the two studied seasons, respectively . All tolerant rootstocks retained more $\mathrm{Na}^{+}$in roots than that accumulated in leaves. In Picual cv. this response become apparent as salinity increased in $\mathrm{Kal} / \mathrm{Pic}$ plants, root $\mathrm{Na}^{+} /$leaf $\mathrm{Na}^{+}$increased from (1.122 to $1.833) \&(1.128$ to 1.801$)$ where in Kal / Kor plants this ratio decreased from (1.099 to 0.734$) \&$ (1.097 to 0.685$)$ while there is a slight increase (1.142 to 1.237$)$ \& (1.097 to 1.205$)$ in Kal/ Far plants, as salinity increased from $400 \mathrm{ppm}$ (control) to $8000 \mathrm{ppm}$ in 2002 and 2003 seasons, respectively. These results similar to that reported by Ferguson et al (2002) on pistachio budded plants.

Similar to $\mathrm{Na}^{+}$, chloride increased with increasing salinity in leaves and roots of all grafted plants comparing with control. The results showed that $\mathrm{Cl}^{-}$was lower in leaves and higher in roots than $\mathrm{Na}^{+}$in all grafted plants irrigated with saline water in different degrees.

Leaf analysis showed that plants of the sensitive rootstock (Koroneiki cv.) accumulated sizable amount of $\mathrm{Na}^{+}$and $\mathrm{Cl}^{-}$in the leaves in contrast to plants of tolerant rootstock (Picual) which exclude both ions $(\mathrm{Na} \& \mathrm{Cl})$ from the leaves.

These results are in line with those found by Bondok et al (1995) on Peach, who found that less tolerant rootstock in budded plants contained higher concentration of $\mathrm{Na}^{+}$and $\mathrm{Cl}^{-}$in leaves than tolerant ones. Further more, Michael and Mary (2002) reported that, rootstock can 
Arab Univ. J. Agric. Sci., 13(2), 2005 
impart stress tolerance to the scion and that the beneficial effect of the rootstock is often the exclusion of $\mathrm{Na}^{+}$and / or $\mathrm{Cl}^{-}$ from the scion. Some evidence on the exclusion of toxic ions has been reported for olive cultivars by Therios and Misopolinos (1988); Tattini et al (1992); Atia (2002) and Loepassaki et al (2002).

\section{(b) Nitrogen (N), Phosphorus (P) and Potassium (K) content}

As for $\mathrm{N}, \mathrm{P}$ and $\mathrm{K}$ content in Kalamata leaves as influenced by different rootstocks and increasing salinity level in irrigation water, results of both studied seasons in Table (7) clearly show that significant reduction in the $\mathrm{N}, \mathrm{P}$ and $\mathrm{K}$ content in leaves of the studied grafted plants compared with the control ones. The results show a significant variable effect on $\mathrm{N}$ and $\mathrm{K}$ content in terms of the salinity response of the different grafted plants, For instance, the $\mathrm{Kal} / \mathrm{Pic}$ and $\mathrm{Kal} /$ Fra plants had higher $\mathrm{N} \%$ in leaves than Kal/Kor plants, whereas Kal/ Pic accumulated $\mathrm{K}$ more than the other grafted plants, while $\mathrm{P}$ content in leaves of all grafted plants showed insignificant difference in the two studied seasons. These results are generally in line with those reported by Taha et al (1972); Bartolini et al (1991); El-Sayed et al (1996); Tattini et al (1997); Atia (2002); Loupassaki et al (2002) and Al-Absi et al (2003).

The reduced concentrations of the nutrient combined with the stunting of growth caused by salinity (Therios and Misoplinos, 1988; Loupassaki et al 2002) leads to the conclusion that there is significant suppression of the nutrition of the olive.
Regarding to the interaction between salinity levels and different olive rootstocks on the $\mathrm{N}, \mathrm{P}$ and $\mathrm{K}$ content in leaves, results show that, significant variations were found between grafted plants where $\mathrm{Kal} / \mathrm{Pic}$ exhibited the highest values of $\mathrm{N}, \mathrm{P}$ and $\mathrm{K}$ content, while $\mathrm{Kal} / \mathrm{Kor}$ gave the lowest values in 2002 and 2003 seasons. The least contents of N, P and K were recorded with 8000 ppm salinity applied to $\mathrm{Kal} / \mathrm{Kor}$ plants in both seasons.

However, the best markers for determining the relative salt tolerance among these rootstocks are $\mathrm{Na}^{+}$and $\mathrm{Cl}^{-}$contents in leaves and roots as well as proline content in leaves.

In conclusion, salinity had increased $\mathrm{Na}^{+}$and $\mathrm{Cl}^{-}$concentrations in leaves and roots, to different degrees and reduced growth of Kalamata olive cultivars grafted on the three rootstocks. The relative tolerance of the three studied rootstocks appears to be due to the characteristics of the rootstock in response to salinilized irrigation water and the ability of the root to exclude $\mathrm{Na}^{+}$and $\mathrm{Cl}^{-}$from the leaves. Date show that Kal/Kor (sensitive rootstock) plants had the highest concentration of $\mathrm{Na}^{+}$and $\mathrm{Cl}^{-}$in leaves and appeared to be the poorest plants, whereas $\mathrm{Kal} / \mathrm{Pic}$ (the most tolerant rootstock) exhibited the greatest salt tolerance followed by $\mathrm{Kal} / \mathrm{Fra}$ (the less tolerant one) this is clearly related to the different abilities of the rootstocks to exclude $\mathrm{Na}^{+}$and $\mathrm{Cl}^{-}$ions from the leaves.

\section{REFERENCES}

Al-Absi, K.; M. Qrunfleh.; T. AbuSharar; K. Tanino; R. Arora; B. Grares; M. Griffith; LV. Gusta; O. Junttila; J. Palta and M. Wisniewshi (2003). Mechanism of salt tolerance of two olive 
(Olea europea L.) cultivars as related electrolyte concentration and toxicity. Acta. Hort. 681: 281-290.

A.O.A.C. (1970). Official Methods of Analysis of Assiociation of Official Agriculture Chemists $10^{\text {th }}$ Ed. Washington, D.C., U.S.A.

A.O.A.C. (2000). Official Methods of Analysis. Potassium and Sodium in Plants. $17^{\text {th }}$ Ed. Gaithersburg, Maryland, USA.

Atia, Sherin. A. (2002). Studies on Growth of Olive Plants Under Salt Stress. pp. 67-82. Ph.D. Thesis Faculty of Agriculture, Cairo Univ. Egypt.

Banuls, J.; F. Legaz and E. Prima Millo (1990). Effect of salinity on uptake and distribution of chloride and sodium in some citrus scion rootstock combinations. J. Hort, Sci., 65:715 - 724.

Bartolini, G.; C. Mazuelos and A. Troncoso (1991). Influence of $\mathrm{Na}_{2} \mathrm{SO}_{4}$ and $\mathrm{NaCl}$ salts on survival, growth and mineral composition of young olive plants inert sand culture. Adv. Hort Science., 5: 73-76.

Bates, L.S.; R.P. Waldren and I.D. Teare (1973). Rapid determination of free Proline for water-stress studies. Plant Physiol.. 39: 205-207.

Bernstein, L. (1965). Salt tolerance of fruit crops. Agric. Info., Bull. No. 292, 8 pp., USDA, Washington. D.C.

Bondok, A.; H. Tawfic; A. Shaltout and N. Abdel-Hamid (1995). Effect of salinized irrigation water on growth and chemical contituents of Floridaprince peach cultivar budded on different peach rootstocks Assiut. J of Agric. Sci. (26) 1: 149-171. Egypt.

Cooper, W.C.; B.S. Gorton and E.O. Olson (1952). Ionic accumulation in citrus as influenced by rootstock and sci- on concentration of salts and boron in the substrate. Plant Physiol. 27: 191-203.

Duncan, D.B. (1955). Multiple range and multiple F. tests. Biometrics 11:1-42.

El-Sayed, Emtethal. H.; M.E. El-Saied; A.H. El-Sherif and S.A. Sari El-Deen (1996). Chemical studies on the salt tolerance of some olive cultivars. Olivae, 64: 52-57.

Ferguson, L.; J.A. Poss; A.R. Grattan; C.M. Grieve; D. Wange; C. Wilson; T.J. Donovan and C.T. Chao (2002). Pistachio rootstocks influence scion growth and ion relations under salinity and boron stress. J. Amer. Soc. Hort. Sci. 127 (2): 194-199.

Flower, T.J.; P.F. Troke and A.R. Yeo (1977). The mechanism of salt tolerance in halophytes. Ann. Rev. Plant Physiol., 28: 89-121.

Hartmann, H.T. and D.E. Kester (1968). Plant Propagation Principles and Practices. pp. 222-230. Prentice. Hall., Inc., Englewood Cliffs, New Jersey, USA.

Hoagland, D.R. and D.I. Arnon (1950). The water culture method for growing plants without soil. Calif. Agric. Exp. Sta. Circ. 347: 1-32.

Jackson, M.L. (1973). Soil Chemical Analyses Advanced Course, $2^{\text {nd }}$ Ed. 895 pp., Department of Soil Science, Univ. of Wisconsin, Madison. Wis.

Jacobson, L. and J. Ortli (1956). The relation between iron and chlorophyll contents in chlorotic sunflower leaves. Plant. Physiol. 31: 199-204.

Jose, L. Moya; Francisco, R. Tadeo; Aurelio Gomez-Cadenes; Edusrdo Primo-Millo and Manuel Talon (2002). Transmissible salt tolerance traits identified through reciprocal grafts between sensitive Carrizo and tolerant Cleopatra 
citrus genotypes. J. Plant Physiol. 159: 991- 998.

Kaul, M.K. (1981). Studies on salt tolerance in guava. J. Plant Nutri. 4:131-141 ( Hort. Abst, 53:1372).

Leon, J.M. and M. J. Bukovac (1978): Cuticle development and surface morphology of olive leaves with reference to penetration of foliar applied chemicals. $\boldsymbol{J}$. Am. Soc. Hort. Sci. 103: 465-472.

Lloyd, J.; J.P. Syvertsen and P.E. Kriedemann (1987). Salinity effect on leaf water relation and gas exchange of Valencia orange, Citrus sinensis L. Osbeck, on rootstocks with different salt exclusion characteristics. Austral. $J$. Plant Physiol. 14: 605-617.

Loupassaki, M.H.; K.S. Chartzoulakis.; N.B. Digalaki and I.I. Androulakis (2002). Effect of salt stress on concentration of nitrogen, phosphorus, potassium, calcium, magnesium, and sodium in leaves, shoots, and roots of six olive cultivars. J. of Plant Nutrition 25 (11): 2457-2482.

Michael, V. Mickelbart and Mary Lu. Arpaia. (2002). Rootstock influences changes in ion concentration, growth and photosynthesis of Hass avocado trees in response to salinity. J. Amer. Soc. Hort. Sci. 127(4): 649-655.

Pregl, F. (1945). Quantitative Organic Micro Analysis. $4^{\text {th }}$ Ed. pp. 126-129. Churchill. LTD. London.

Puritch, G.S. and A.V. Barker (1967). Structure and function of tomato leaf chloroplasts during ammonium toxicity. Plant Physiol. 42: 1229-1238.
Saric, M.; R. Kastrol; R. Caric and I. Geric (1967). Effect of salinity on some citrus rootstocks. Prak Fiziol. Anjiga, P. 215 (Hort. Abst. 38: 319).

Snedecor, G.W. and W.G. Cochran (1980). Statistical Methods. $6^{\text {th }}$ Ed. pp. 365-372. Oxford, London.

Stewart, G.R. and J.A. Lee (1974). The role of proline accumulation in halophytes. Plant, 20: 279-289.

Syvertsen, J.P.; B. Boman and D.P.H. Tucker (1989). Salinity in Florida citrus production. Proc. Florida State. Hort Soc., 102: 6-64.

Taha, M.W.; E. El-Azab and Z. Fadiah (1972). Ionic leaf accumulation in grapes, guava and olive plants as affected by the salinity of irrigation water. Alex. J. Agr. Res. 20: 299-309, Egypt.

Tattini, M.; P. Bertoni and S. Caselli (1992). Genotypic responses of olive plants to sodium chloride. J. Plant Nutr. 15: 1467-1485.

Tattini, M.; C. Ponzio; M.A. Coradeschi; R. Tafani and M.L. Traversi (1994). Mechanism of salt tolerance in olive plants. Acta, Hort. 356: 181-183.

Tattini, M.; L. Lombardini and R. Gucci (1997). The effect of $\mathrm{NaCl}$ stress and relief on gas exchange properties of two olive cultivars differing in tolerance to salinity. Plant and Soil. 197: 8793.

Therios, I.N. and N.D. Misopolinos (1988). Genotype response to sodium chloride salinity of four major olive cultivars (Olea europea L.). Plant. Soil. 106: 105-111. 
بحلة التحاد الجامعات العربية للدراسات والبحوث الزراعية ، جامعة عين شمس ، القاهرة ، 13(2) ، 399 - 417 ، 2005 تاثير الرى بالماء المملح على النمو والمحتوى الكيميائي لصنف الزيتون كلاماتا المطعوم على اصول زيتون مختلفة

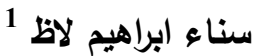

$[25]$

1- قسم بحوث الزيتون وفاكهة المناطق شبه الجافة - معهد بحوث البساتين - مركز البحوث الزراعية الجيزة

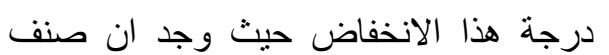

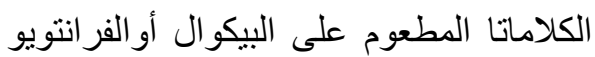

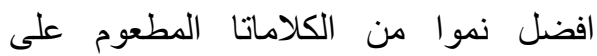

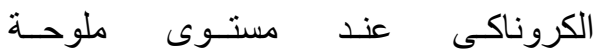

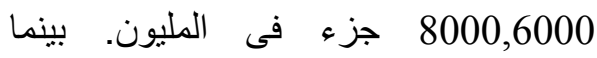
اظهرت النتائج فى النباتات الغير معاملة

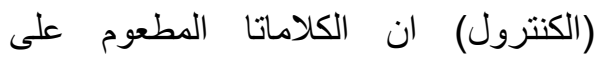
الكروناكى كان افضل فى النمو الخضرى من الكنائ

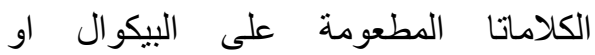
الفر انتويو.

ادت المعاملة بالرى بالماء المملح الى الى التئل

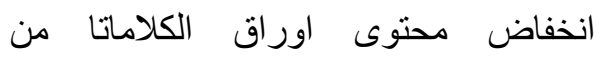





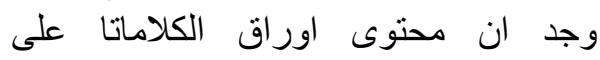

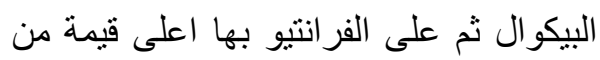
الكلورفيل مقارنة بمحتوى اوراق الكلاماتا

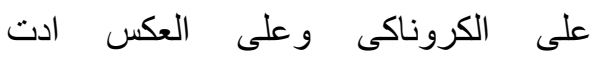

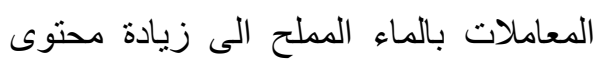

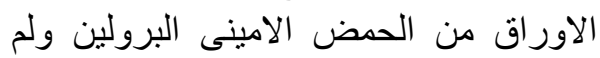

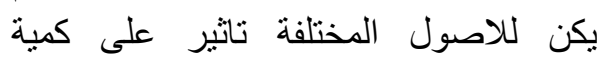
البرولين فى اور اق الطعم.
أجريت هذة الدراسة لاختبار تأثير الرى بالماء المملح على النمو و المحتوى الكيميائي لصنف الزيتون كلاماتا المطعوم على ثلاثنة

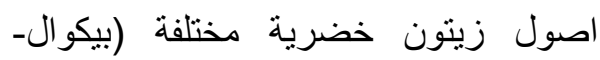

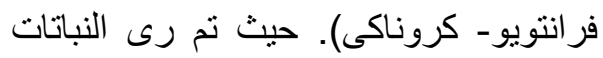

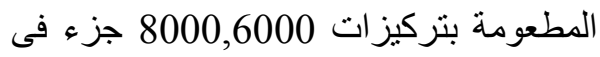
المليون، عند مستوى صوديوم مدمص (12) من مخلوط المحلول الملحى (كلوريد

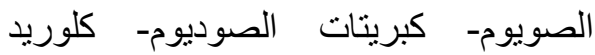


البوتاسيوم) فى حين نم رى نباتات مطعومة البرات اخرى بماء الصنبور للمقارنة وقد الظهري

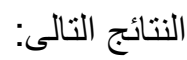
اختلاف فى مدى الاستجابة للرى بالماء

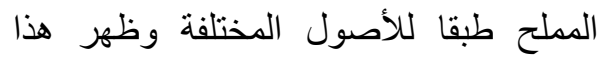

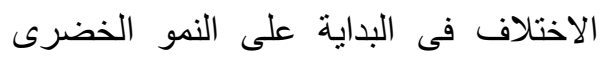

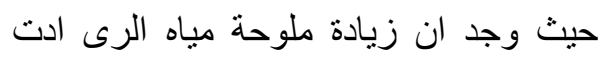

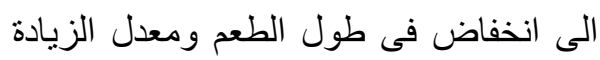

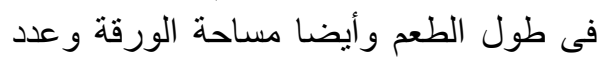

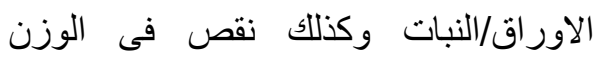

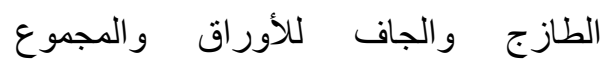
الجذري. وكان لاختلاف الاصل تاثثر على لوراف 


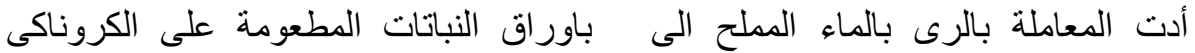

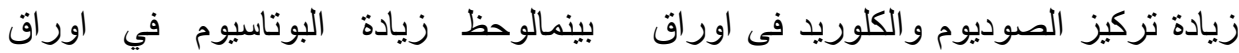

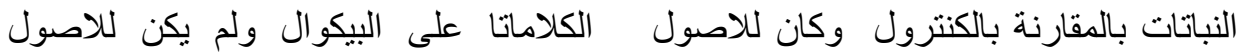

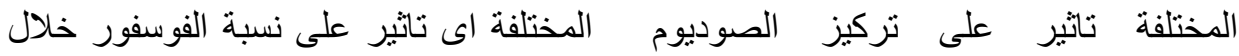

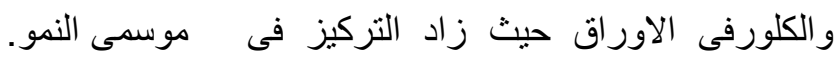

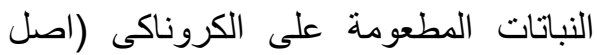

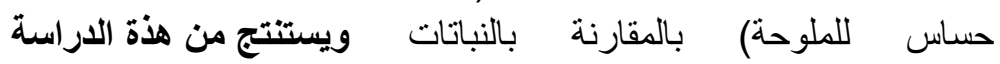

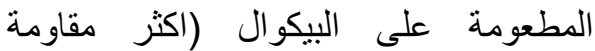
ان نباتات الكلاماتا المطعومة على اصل المجل للملوحة) أو الفرانتيو (متوسط المبكو المقاومة)

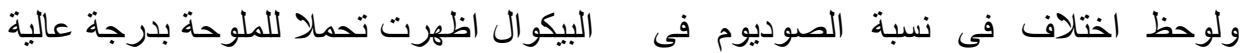

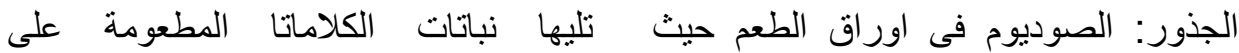

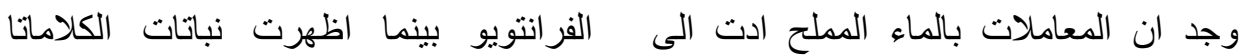

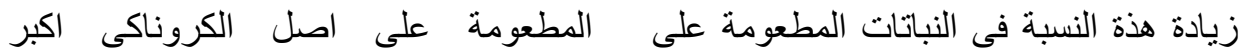

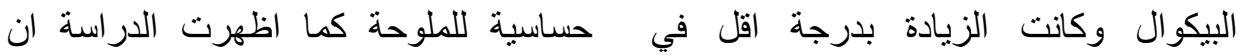

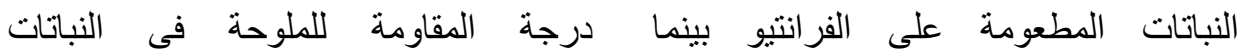

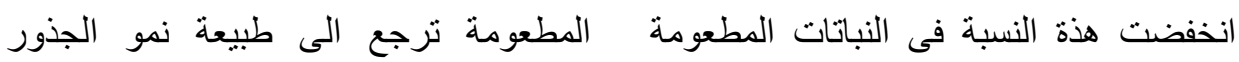

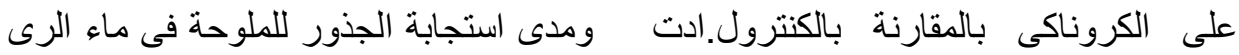

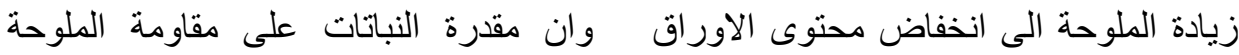

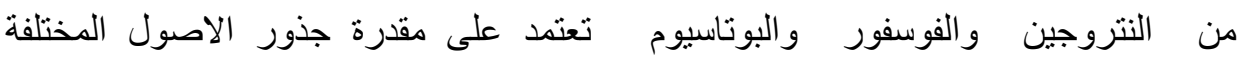

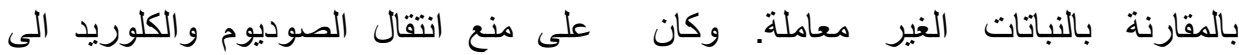

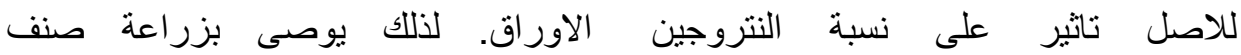

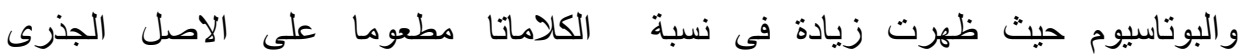

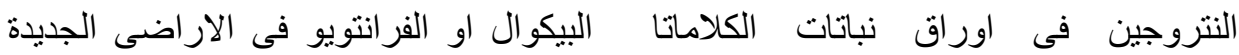



\footnotetext{
تحكيم: أ.د محمد أبو رواش على بدر

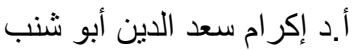

